\title{
Preface
}

If this book had a single beginning, it was a chamber theatre production of five Grace Paley short stories that I directed at DePaul University in 1985. As I worked with my cast and crew on that show, I became increasingly intrigued by Paley's innovative narrative techniques. So, my first thanks go to the students who worked with me on that show, especially Ken Beider, Pattey Cook, and Pamela Schroeder. Two years later, Mary Argianas and Mitra Emad performed two Paley short stories for another chamber theatre production, and again I learned about Paley from directing them in their performances. I first worked out some of the language issues explored here with my gender and communication class in 1986 and have discussed Paley, language, narrative structure, and mutedness with some eight other classes since then. I am indebted to the many DePaul students who have helped me develop these ideas.

Many friends and colleagues around the country contributed support, encouragement, criticism, and ideas. Several of these must have special thanks. Joanne Devine read the manuscript in various stages, offering helpful comments and bibliographic information. She has been a source of encouragement, ideas, and information since I first became interested in questions of language and gender. Lynn Christine Miller read and commented on an earlier version. Carol Cyganowski read a draft of the entire manuscript with enormous dispatch and then helped me to see what I needed to do to get the project into its final form. My book group, Marla Cass, Diane Krall, Miriam Pickus, Carol Sadtler, Susan Schleef, Elaine Stocker, and Sandra Whisler, made the manuscript the topic of one month's 
discussion. Their interest and comments helped me to keep faith in the project and refine my ideas. They also served as the collective model for the intelligent, well-read, feminist, nonacademic reader whom I hoped would form part of the audience for this book. Kristin Langellier read and commented on the section that traces the connection between Paley's stories and women's personal narratives, a section that was inspired by Langellier's own work. My two reviewers for University of Texas Press made a number of suggestions that strengthened the book. Frankie Westbrook, my editor, along with the rest of the staff at U.T. Press, has made publishing this book easier than I had any reason to expect it could be. After Marjorie Piechowski helped me to put together grant proposals seeking support for this work, Paul H. Gray, Beverly Whitaker Long, James Malek, Jean Haskell Speer, and Carol Simpson Stern wrote in support of those proposals. DePaul University gave me a one-year research leave and summer support while I wrote. The National Endowment for the Humanities provided me with a summer stipend. Mitra Emad helped with the final tasks of proofreading and indexing. My parents, Eldred and Marjorie Taylor, contributed, as always, their collosal faith in me. At the end, Lucia Taylor gave me the happiest of reasons to hurry up and get it done. Throughout this project, Carol Sadtler talked with me about these ideas, read multiple versions, made suggestions, and took my work seriously (without ever losing her sense of humor). Writing this book would not have been nearly as much fun without her.

Finally, I owe a debt to Grace Paley. When I called up without an introduction and wanted an interview, she agreed to talk to me about her work. She was generous with her time and patient with my inexperienced approach to interviewing. But more than that, I thank her for these stories, which have given me so many happy hours of reading and study. 


\section{Grace Paley}

Illuminating the Dark Lives 
THIS PAGE INTENTIONALLY LEFT BLANK 